\title{
The April/May 2011 Gubernatorial Poll in Imo State: A Triumph of the Masses
}

\author{
Ikenna Odife*
}

\section{Abstract}

Election provides a platform for people to elect those who direct the affairs of the state for a specific period. In this sense, its outcome could either be an acceptance of the leadership style of those in power, hence a re-election or a rejection, in which case they are voted out of office. Most regrettably, in the Nigerian context and in Imo State in particular, the results of the elections conducted in the past eight years could hardly be said to reflect the wishes and aspirations of the electorate. But the result of the April/May 2011 gubernatorial election appears to be a departure from this untoward trend. This paper discusses the nature, process and outcome of the said election and argues that the departure was occasioned by the doggedness and determination of the masses of Imo State to emancipate themselves from the stranglehold of self perpetuated leaders and political elite. It contends that the result of the election was a manifestation of innate revolutionary impulse inherent in the masses of Imo State which found vent in the "one man one vote and your votes must count" slogans of President Goodluck Ebele Jonathan, as well as the popularity and charisma of the APGA gubernatorial candidate, Owelle Rochas Okorocha.

http://dx.doi.org/10.4314/ujah.v13i1.9

\section{Introduction}

The April/May 2011 gubernatorial election in Imo State is indeed, a landmark event in the annals of the history of the state. In the first place, the result de-mystified the incumbency factor in election. Again it overthrew the powers and influence of self-perpetuated political class and leaders of thought, who 
had for the past twelve years held the entire state to ransom. Finally, it nullified the Imo Charter of Equity enunciated by a few powerful individuals to perpetually make a fiefdom of the state which they and their acolytes would control and exploit. This makes the study of the nature, process and outcome of this election imperative. This paper embarks on this task with a view to establishing the underlying reasons that made its outcome possible and also to provide useful insights in its significance on the politics and economy of the state.

In order to address this task, this paper is divided into four sections. The first addresses the dynamics of politics and society of Imo State. The second x-rays the build up to the April/May 2011 gubernatorial election. The third discusses the masses element of the election while the fourth section provides the summary and concluding remarks.

\section{The Dynamics of Politics and Society in Imo State}

This paper, adopts as Imo State, the state that came into existence with the 1991 states' creation exercise. This is significant because the state has since remained a distinct geopolitical and administrative entity within the Nigerian nation state. It consists of three geo-political zones, namely, Orlu, Owerri and Okigwe. These zones could be further split into areas or divisions. These constitute blocks within the zones. The areas or divisions like the zones constitute political power centres which could be manipulated by politicians and administrators to build alliances and, in the distribution of social services, amenities and infrastructure, respectively. A rather unfortunate feature of the geo-political structure of the state is the obvious disparity in the distribution of government infrastructure, population and number of local councils that make up each zone: whereas Orlu zone has twelve local councils out of the twenty-seven in the state, Owerri and Okigwe share the balance with nine and six local councils, 
respectively. This certainly confers Orlu zone definite advantages in the power play and political equation of the state. On the other hand, Owerri zone has the advantage of hosting the state capital, being the most populous and also has the highest number of the state's population engaged at different cadres in the state civil service. Most government establishments and infrastructural facilities are also located there. Finally Okigwe is the least in population with the lowest concentration of infrastructural facilities and government presence. Perhaps, with this obvious specter of disparity, inequality and imbalance in the geo-political structure, some individuals felt there was need to contrive a strategy that would guarantee the various zones a fair and equal access and share of political power, hence the Imo Charter of Equity. This was the brain child of few political patrons from each zone, notably Chief Arthur Nzeribe from Orlu, Chief Emmanuel Iwuanyanwu from Owerri and Chief John Enyiogasi of Okigwe.

This arrangement has received varied comments from indigenes of the state. While some acquiesce to it, others vehemently oppose it. Dr. U.C.C Nwogwugwu sees it "as a veritable arrangement that would allow development permeate all sections of the state". ${ }^{1}$ He argues that since the three zones of the state are highly disproportionate in terms of population and the number of local councils, the arrangement would grant the marginal zones access to power and also the opportunity to address their specific development needs whenever the governor of the state emerges from such area. With recourse to hindsight he cites the examples of Umuahia and Avutu-Obowo which owe the government of presence in the areas to administration of Dr. Michael Okpara and Chief Samuel Mbakwe, respectively. ${ }^{2}$ Mr. Livinus Okeke, however, holds a divergent view. He sees the zoning principle or Charter of Equity as "a feast for clannishness and mediocrity". ${ }^{3} \mathrm{He}$ argues 
that "any person who strives for, and is desirous of being the governor of the state should be one who could see the entire state as his constituency and be fair and just to all sections in the distribution of government amenities". "By so doing", he argued, "primordial attachment to clan and nativity would cease and patriotic sentiment and loyalty to the state will be enthroned. ${ }^{5}$ Dr. Johncliff Nwadike was very critical of the zoning structure and arrangement. He questions "who mandated the few individuals that drew the charter to speak on behalf of the generality of Imo State people?"6 He describes the initiators of the charter as "feudal lords with intent to make a fief of the state; to be exploited by them and their cronies"7. In his view, "the charter of equity was an arrangement by political godfathers to harmonize their interest and minimize dispute and disagreement over the allocation of the state's resources among themselves and their cronies". ${ }^{8}$ Which ever position one may wish to take, the Charter of Equity is central and critical in understanding and analyzing power-play, politics and elections in Imo State.

Another significant feature of polities in Imo State and indeed, the entire Igboland is the impact of the enterprise of Christian missions. It has been observed that the Christian missions in their effort to proselytize Igboland, polarized the society along denominational lines. This permeates all spheres of public life. For instance, the clergy and laity of each denomination would prefer their member to occupy public position, even when it could be obvious that he may be less competent than his opponent. In the same vein, political office seekers would strive to maintain a balance by addressing and harmonizing differing denominational interests and persuasions. It would for instance, amount to political suicide for a Roman Catholic gubernatorial candidate to nominate a Roman Catholic deputy. Thus, a Catholic-Catholic ticket 
would be viewed with resentment by the Anglican and vice versa.

The rise of Pentecostalism and charismatic Christian groups has left in-prints in the politics and social obligation of the average Igbo person. The numerical strength of these groups makes them indispensable in politics and election. It has been observed that in some cases, political office seekers build alliances with them for the purpose of attracting their votes. ${ }^{10}$ Other groups that play phenomenal role in the politics of the state include the Imo League of professionals. Leadership of the major markets Association, Town Union Leaders, Artisan groups and most especially the motorcycle taxi operators, popularly known as 'okada' riders. The latter constitute the bulk of what could be described as the masses of Imo State. Their ubiquity and boisterous conduct make them a bloc or pressure group one would ignore at his political peril.

The traditional rulers and their umbrella organization, Imo State Council of Traditional Rulers constitute a major force in the politics of the state. However, their 'unalloyed' loyalty and support is to the government in power. The patronclient relationship between them and the state government accounts for this. This could be explained, perhaps, by the fact that their recognition and access to power are dependent on the disposition of the state governor. More often than not they blow the trumpet of their patron. Any utterance conduct or action viewed as opposing or at variance with that of the governor could attract summary withdrawal of Certificate of Recognition and deposition of such 'erring' traditional rulers. Consequently, they assure the governor of their unflinching support in all circumstances. 


\section{The Build-Up to the April/May, 2011}

\section{i. Governorship Election in Imo State 1999 - 2007}

Very significant to the politics of Imo State and the contest of the April/May 2011 gubernatorial election was the tacit agreement made by some notable politicians in the state on power rotation among the zones, otherwise known as Imo Charter of Equity and the primary elections conducted by the leading political parties in the state, namely All Peoples Party (APP) and Peoples Democratic Party (PDP), to nominate their respective gubernatorial candidates for the 1999 governorship election. The APP's primary election was less fiercely contested and Engr. Ezekiel Izuogu from Orlu zone easily emerged the party's gubernatorial candidate. Certainly, Chief Izuogu's political profile ranked far higher than that of other contestants in the party.

The PDP on the other hand, had three frontline and major contestants in the primaries to nominate her party's candidate. They were Chief Humphrey Anumudu from Mbaitoli/Ikeduru area of Owerri zone, Chief Greg Mbadiwe and Owelle Rochas Okorocha, all from the Ideato area of Orlu zone. The state chairman of the party was Chief I.D. Nwoga, a seasoned bureaucrat from Owerri zone. Attempts by the party to organize credible and conclusive primary elections were frustrated by the trio. Each employed all possible instruments, wealth, violence, intimidation and blackmail to ensure victory. On account of the blatant show of power exhibited by these in the contest of their party's primaries, the APP in their campaign slogan branded PDP "a party of raschal"11. This trend became a source of worry to the party leadership in the state as its credibility was eroding fast. In order to ensure a reversal of this trend and enhance the party's electoral chances, it nominated a green horn and next to the major contestants, 
Chief Achike Udenwa, who hails from Orlu zone, as the party's gubernatorial candidate.

It does appear that this fortuitous nomination of the gubernatorial candidates of the two main political parties from Orlu zone spurred the trio of Chief Arthur Nzeribe, Chief Emmanuel Iwuanyanwu and Chief John Enyiogasi or Orlu, Owerri and Okigwe zones respectively to draw up the Imo Charter of Equity. ${ }^{12}$ This was not intended to be legally binding but could only be honoured for political expediency.

Chief Achike Udenwa emerged victorious in the 1999 gubernatorial election and with his deputy had a two-term administration of Imo State. As regards the second term ticket, they were beneficiaries of the gratis of the National leadership of the PDP which, with the exception of Anambra State, gave automatic tickets to incumbent governors on the party's platform to run for a second term. ${ }^{13}$

The re-election of the Chief Achike Udenwa for a second term was highly controversial as his party (PDP) did not appear to win majority of the votes cast in the election. Prior to the election, the Independent National Electoral Commission had registered the All Progressives Grand Alliance (APGA) as a recognized political power. This political party was largely a regional one which provided a rallying point for the Igbo ethnic group. Its presidential candidate, Chief Emeka Odumegwu Ojukwu was known to wield enormous political clout across Igboland. This manifested in the fanatic support and massive votes the party polled in the 2003 gubernatorial elections in the states of the South East. Arguably, APGA won the Imo State governorship election and virtually all the Senate, National and State Assembly seats. Ironically, the PDP through the instrumentality of INEC returned her own candidates winners of the election, and further manipulated the judicial system to frustrate the APGA candidates from recovering their stolen 
mandates at the Election petition tribunals. ${ }^{14}$ It is important to remind us here, as it has been stated elsewhere that the exceptional case in this matter, that of Mr. Peter Obi of Anambra State, was made possible not so much by this tenacity and doggedness to fight for his mandate as it was due to the misunderstanding and rift between Chris Ngige on one hand and his 'godfathers' (political patrons) and the PDP leadership on the other. ${ }^{15}$

A dispassionate assessment of the two-term Chief Achike Udenwa administration would tend to show that he attempted to rivet the dominance of Orlu zone in the politics and public service of Imo State. The distribution of social and infrastructural amenities and appointments into key and juicy public offices in the state were skewed in favour of Orlu zone. For example, the Secretary to the State Government (SSG,) Chief I.M.O Umunna, the Chief of Staff, Government House, Dr. Vincent Udokwu, as well as two successive ViceChancellors of Imo State University, all hail from Orlu zone. Also employment into administrative and junior cadres in the civil service, government departments, parastatals and institution was in favour of Orlu zone. This could be attested to by the dominance of the speakers of Orsu-Isuama dialect of Igbo language amongst the civil servants recruited between 1999 and 2007 in the state. In an exasperating reaction to this apparent preponderance of people from Orlu zone in civil service, key government offices and so on, Dr. Inyama, in an informal communication with the writer bemoaned "ndi Orlu alugbuola anyi" meaning "Our Orlu leaders have subordinated us". ${ }^{16}$ By the end of Governor Chike Udenwa's second term in the office, Orlu zone had almost overtaken Owerri as the numerically preponderant group in Imo State Civil Service. It may not be totally out of place to argue that those who invoke the Charter of Equity as a basis for even access to power in 2011 governorship election may be reacting to the pattern of 
administration Chief Achike Udenwa administration bequeathed the state.

\section{ii. Achike Udenwa and Senator Ifeanyi Ararume Feud and the 2007 Gubernatorial Election}

A landmark event in the power struggle in Imo State before the 2007 gubernatorial election was the feud between Governor Achike Udenwa and Senator Ifeanyi Ararume, representing Okigwe zone. This feud arose over the successor of Achike Udenwa at the expiration of his second term in office in 2007. While Senator Ararume intended to occupy "Douglas House", Governor Achike Udenwa felt otherwise. As it has become customary in Nigerian politics, outgoing governors labour assiduously and relentlessly to determine their successors. Achike Udenwa, perhaps, considered any person but Senator Ararume eligible for the post. Senator Ararume on the other hand, felt he had the political clout not to just to contest but also to wrench power from Udenwa. He formed a political organization, "the Destiny Group", whose influence and membership traversed the political wards in the state, but with its inspirational headquarters at Abuja, hence they were branded "Abuja politicians" by their rivals to vie for the PDP governorship primaries. This organization made unrelenting and unceasing efforts to infiltrate the ranks and leadership of Imo State House of Assembly. Perceived Ararume loyalists and supporters in the House were fished out, harassed and pilloried by Governor Achike Udenwa, Nevertheless, they remained undaunted. ${ }^{17}$

Governor Achike Udenwa on his part employed his political organization the "Redemption Group" to consolidate his hold on power and the party machinery in the state. The state's resources and perks of office were generously dispensed to maintain this structure. Because the members were based in the state as against Ararume's Abuja base, it was 
called 'ono ngo ono' meaning, stay put, 'on the ground 'or 'immovable'.

The high point of this feud was the primaries for the nomination of PDP gubernatorial candidate for the state. It was alleged that Governor Achike Udenwa supported a U.S. based attorney at law and member of the defunct Imo State House of Assembly (1991 - 1993), Chief Ike Ibe from Okigwe zone. Chief Ibe put up an abysmal performance at the primaries. Some reasons have been adduced for this. In the first place, Chief Ibe was based in the U.S. and alien to the main line power bloc of PDP in the state. Again, some key party members were aggrieved and displeased with Chief Udenwa for not projecting his deputy, Engr. Ebere Udeagu, who gave him eight years of loyal service, as a possible successor. ${ }^{19} \mathrm{By}$ and large, Achike Udenwa failed in his attempt to influence the nomination of the PDP gubernatorial candidate.

As was to be expected, Senator Ifeanyi Ararume ran for the primaries. He chose a formidable running mate, Chief Ezenwa from Ezenifite Mbaise. With enormous financial resources and support from his political network, Senator Ararume beat all the other contestants. But for reasons not discernable to this writer and after several intrigues, Chief Charles Ugwu, from Okigwe zone, who placed tenth in the contest, was given the party's ticket. Senator Ararume resorted to litigation. After a protracted legal tussle, the Supreme Court declared him the duly nominated candidate in the PDP gubernatorial primaries. ${ }^{20}$ But the entire leadership of the PDP considered Senator Ararume's audacity and temerity in asserting his rights in the PDP primaries an affront to its authority and frustrated him at the polls by denying him support. Consequently the PDP put up an abysmal performance in the April 14, 2007 election. However, the States' Resident Electoral Commissioner, cancelled the 
election on phantom reasons of "violence and massive irregularities". ${ }^{21}$

\section{iii. The Emergence of Chief Ikedi Ohakim as the Governor of Imo State in $\mathbf{2 0 0 7}$}

The emergence of Chief Ikedi Ohakim as the governor of the state on the ticket of the Progressive Peoples' Alliance (PPA) is arguably the most dramatic event in the conduct of elections in Imo State. He was not seen as a strong contender to the office, he did neither embark on an elaborate campaign nor have the clout to win the gubernatorial election. He had lost woefully in the PDP primaries for the nomination of gubernatorial candidate. Perhaps, this was a manifestation of his clout in the party in particular and Imo State in general. Perceptive analysts in the state are wont to opine that he ran for the PDP primaries principally to shore up his political profile in anticipation of an appointment at the state or national level. ${ }^{22}$ However, with the INEC recognition of the Governor Orji Uzo Kalu of Abia State financed PPA, he decamped from the PDP and ran as the PPA's gubernatorial candidate. He nominated a fellow member of the Anglican denomination and relatively unknown political quantity, Lady Ada Okwuonu from Mbaise area of Owerri zone as running mate. Certainly, the duo was among the least formidable amongst the contestants for the governorship position. In the first place, Lady Okwuonu did not command a towering image in the polities of Mbaise area; not to mention Owerri zone and Imo State. Again, an Anglican-Anglican ticket was un-strategic in a state where rivalry between the Anglican and Catholic denominations is rife. In fact it is un-thoughtful of any serious contender to public office in Igboland to discountenance this in forging political alliance and choice of running mate. ${ }^{23}$

However, fate turned to his favour when the State Resident Electoral Commissioner cancelled the April 14 
gubernatorial election on grounds of "violence and massive irregularities". This cancellation came as official results from the twenty-four of the twenty-seven local councils had been released with Chief Martins Agbaso of APGA maintaining a comfortable lead. The most astonishing and confounding aspects of the cancellation to the Imo electorate and election observers and monitors was that the State Assembly election conducted simultaneously in the same ballot box was upheld. ${ }^{24}$

Two main theories have been advanced to explain this cancellation. The first is of the opinion that Chief Martin Agbaso and then Governor Achike Udenwa disagreed on the post election modus Vivendi, hence the latter made recourse to then INEC boss, Professor Maurice Iwu, who directed the state Residence Electoral Commissioner to cancel the election to provide opportunity for a more amenable candidate to emerge as governor. ${ }^{25}$ The second holds that the election was cancelled to pave way for a candidate from Okigwe zone to emerge as governor. Thus, displeased with the seeming emergence of a candidate from Owerri zone, Chief Agbaso, as the governor and as Senator Ifeanyi Ararume was already estranged with the PDP and presidency, Professor Iwu gave consent to the State Residential Electoral Commissioner to cancel to election. He personally identified Chief Ikedi Ohakim as the candidate eligible to be 'ordained' a governor. ${ }^{26}$

Subsequent developments tend to lend credence to the latter position, for on assumption of office, Governor Ohakim appointed Professor Iwu's brother, Chief Cosmas Iwu, the Secretary to the State Government. Again, the invocation of the Charter of Equity doctrine to justify Ohakim's emergence as Governor and basis for re-election by Okigwe zone leaders of thought further vindicate this.

Be that as it may, Chief Ohakim was declared winner of the re-scheduled election held on $28^{\text {th }}$ April, 2009. But before then, Chief Agbaso had challenged the cancellation of 
the April 14 election in a Federal High Court. The reaction Agbaso's litigation evoked and its consequences on Ohakim's administration will be discussed in the subsequent section of this paper.

\section{iii. Challenges of Governor Ikedi Ohakim's Administration}

It would appear that the majority of Imo electorate was $a b$ initio not enamoured with the administration of Chief Ohakim. This may not be unconnected with the circumstances surrounding his emergence as governor. The credibility question would explain the myriads of challenges and certain misconceptions that trailed public perception of his policies and programmes for the development of the state.

The first challenge of his administration was to overcome the problem posed by functioning with a legislature composed of members of another political party, the PDP. It is believed that it took so many consultations and dialogue, veneered with enormous pecuniary exchanges, with the state legislature to constitute the State Executive Council, approve his special Assistants and Advisers to kick start the administration. Similar measures were also employed to win the support of influential power brokers in the state. ${ }^{27}$

Furthermore, lacking in the grass root support upon which to build the necessary political structure and consolidate hold on power, he formed the 'Green and Green' and "The New Face of Imo" organizations in all political wards and local councils of the state. The conspicuous life style and sudden change in the consumption patterns of the members of these organizations, even as pensioners, teachers, and civil servant were owed for many months, portrayed the profligacy of his administration, to the dismay of the people. ${ }^{28}$

Again, he was besieged with a barraged of litigations that tended to distract his focus and drain the states' resources. Among these cases were All Progressive Grant Alliance vs 
Ikedi Ohakim and INEC and Ararume vs Ikedi Ohakim and INEC. These cases were delicate and so protracted that the last was decided by the Supreme Court barely one year to the expiration of the governors four years in office. Commenting on the impact of these cases on Chief Ohakim's administration, a close aide to the governor laments:

Chief Ikedi Ohakim 'Ochinanwata' was distracted by these cases. He settled to govern Imo State after the courts ruled on all the matters against him, and the last was barely one year to the end of his tenure, precisely May 10, $2010 .^{29}$

Another challenge to his administration was the reaction which his attempt to give the state a face lift evoked. In order to keep the environment free of filth, he prohibited the sale of sachet water and to reduce traffic congestion on the roads, he banned the operation of motorcycle taxis (okada). Tricycles (keke) were to replace the motorcycles. But these were supplied at a rate and terms unfavourable to the affected group. The Governor also ordered the demolition of illegal structures and the evacuation of obstructive objects on all the roads in city. This attracted negative responses from the urban poor, most of whom were compelled to re-locate to the outskirts of the city or returned to their villages to eke out a living. Certainly, the groups affected by his restructuring and re-building exercises was embittered with his administration and vehemently opposed his re-election. ${ }^{30}$

The 'Reverend Father saga' was yet another incident that put a serious dent on Chief Ohakim's administration. It was alleged that his security aides manhandled a Reverend father for obstructing the governor's convoy. This generated media hype and the Catholic Church in the state and beyond 
unleashed a stream of invective against the governor. ${ }^{31}$ The explanations and public apology by the office of the governor on the matter could not assuage the anger of the clergy and laity of the Catholic Church. Thus, the Catholic community remained one of the greatest opponents to Chief Ohakim's reelection bid. Allied to the Reverend Father's saga was the alleged physical assault of a journalist attached to the government house by Governor Ohakim himself for reporting a news item viewed inimical to the interest of the state government. $^{32}$

Governor Ohakim's popularity amongst the staff and students of Imo State University was at low ebb. The University was shut down for six months because of his refusal to negotiate with the various trade union groups in the University over the new salary structure and conditions of service. School fees were raised from $\$ 30,000$ to $\$ 150,000$ per session. He made a down ward review of the school fees after his opponents made it a campaign issue. ${ }^{33}$

Some policies of the state that tended to be unpopular and which attracted intense criticism for the administration include; the dredging of Nworie stream at the cost of two billion naira; the dualisation of federal roads in the state capital by placing demarcation blocks at the centre. The re-surfacing of existing roads in the state capital while other roads in state of disrepair were not rehabilitated and the white elephant project of constructing over-head roads to ease traffic flow in the state capital.

The Governor was seen to be boastful, arrogant, haughty and supercilious in his public relations; vengeful and took vendetta against his opponents, insensitive to the plight of the poor and less privileged. ${ }^{34} \mathrm{He}$ was alleged to fraternize and consort with the discredited '419ners' that fled Owerri at the wake of the 1996 Owerri public disturbance through the award 
of contracts and appointment into the Boards of State Agencies. ${ }^{35}$

These developments tended to becloud the notable achievement and the giant strides recorded by the IRROMA (Imo state Rural Roads Maintenance Agency) on rural roads construction and rehabilitation, and ENTRACO in putting a face lift and beautifying the state capital and other urban centres. These were down-played by the masses who were disenchanted with his administration.

In sum, the challenges of Ohakim's administration stem from the contradiction in his emergence as the state governor and failure to effectively manage the material and human resources of the state for optimal result. This was further compounded by the low public image he created for his administration through his conduct and utterances. By and large, governor Ohakim's image, reputation and popularity were at very low ebb, and all attempts he made to remedy and shore them up before the election proved futile and encounter productive. ${ }^{36}$

\section{iv. The Imo State 2011 Gubernatorial Election}

The 2011 gubernatorial election in Imo State was principally a contest by the triumvirate of Chief Ikedi Ohakim, Owelle Rochas Okorocha and Senator Ifeanyi Ararume, to govern the state. It would appear that each enjoyed popular support across the state and had the pocket to finance intensive electoral campaigns. But Chief Ohakim enjoyed some advantages. He was an incumbent governor, had control over the states' resources and media organs and ran the election under the platform of PDP, the party that controls national government and also has a reputation to influence electoral processes to its own advantage. Owelle Rochas Okorocha is reputed to be wealthy and philanthropic, enjoys personal relationship with the hierarchy of the Nigerian armed forces and police, tends to 
associate with the less privileged in the society and the various artisan groups, most especially the motorcycle/tricycle taxi drivers, and so on. But he was seen to be inconsistent and bereft a defined goal in the pursuit of his political career. ${ }^{37} \mathrm{He}$ hails from Orlu zone and ran under the platform of APGA, a political party that enjoys enormous support in the South east.

Senator Ifeanyi Ararume was a two-term senator, had a formidable political network, "The Destiny Group" whose influence span the nooks and crannies of the state, but was viewed to be very ruthless and could exploit hooligans and hoodlums in the state. ${ }^{38}$ It was widely believed that his estrangement with former President Obasanjo and the PDP stemmed from his role in aborting the "third term bid" of former president Obasanjo. He ran under the platform of Action Congress of Nigeria (ACN). He hails from Okigwe zone.

The campaigns for the election were fierce and intense. Apart from reaching the electorate, the three parties intensified efforts to perpetrate their rigging and manipulation strategies and at the same time, strategized to forestall such attempts by others. ${ }^{39}$ But in all, it would appear that the searchlight against rigging, thuggery and result manipulation was focused on Governor Ohakim and the Peoples Democratic Party. And as newspaper reports did indicate, Governor Ohakim made strident attempts to intimidate voters, influence electoral officers and personnel and manipulate the result. These attempt were however, repelled by the vigilant eyes of the masses of Imo State. Perceived collaborators with the governor in this regard received their butt. Traditional rulers, commissioners and top officials in the administration became target groups. ${ }^{40}$

To further ensure free poll and protect the election results from being doctored and manipulated, Artisans, motorcycle/tricycle taxi and commercial vehicle drivers, students and so on, converged at strategic locations in the state 
and constituted themselves into combustible groups ostensibly to explode should the election results be manipulated. Such human presence could be seen as a replication of that which sparked off the 1996 Owerri public disturbances. ${ }^{41}$ Certainly, the condition in the state capital was tense and uneasy. The conspicuous presence of anti-riot policemen and military tanks deployed at strategic locations in the state could not deter and intimidate the public. Anxiety generated by the scenario compelled the States' Commissioner of Police to issue public statements on the commands' preparedness to deal ruthlessly with public actions that might constitute breach of the public peace. $^{42}$

The state's governorship election was conducted in this scenario. The election held on April 23, was inconclusive and a supplementary election was conducted in some wards in Owerri North Local Council and the following local council areas namely, Mbaitoli, Ngor-Okpala and Ohaji/Egbema on $3^{\text {rd }}$ May. Election could not hold in Oguta Local Government Area in the 2011 governorship election because of alleged plans to manipulate the election in the area.

\section{The 'Masses' Element of the Election}

The masses in this paper refer to the social, economic and political segments of the state's population that eke out a living on their efforts, the self-employed and the public/civil servants who were victims of unpopular government policies, and nonbeneficiaries of governments prepends. This group constitutes the majority of the state's population, yet they receive the least attention in the allocation of states' resources. They champion resistance to social ills, oppose anarchy, abuse of due process and rule of law and resent bad governance. They express their discontent to a system through public demonstrations, disturbances and riots. They could be very volatile and combustible in the mode of expressing their grievances. 
The 2011 gubernatorial election in Imo State could be seen as a class struggle and contest between the masses and the comprador elements of the state government. The latter trumpeted their support for the state governor and literarily endorsed his second tenure. Instances abound to buttress this. The guests at the fund raising dinner for Governor Ikedi Ohakin's campaigns was an assemblage of the cream de la cream of Imo state. ${ }^{43}$ The Imo state council of Traditional Rulers under the leadership of Eze Ilomuanya endorsed his reelection and declared him the most eligible and competent candidate amongst the contestants. The Imo league of Professionals and Association of Imo State Town Union organizations issued newspaper releases and advertorials that tended to glorify and eulogize Governor Ohakim and discredit the other contestants. ${ }^{44}$

On the other hand, the masses openly lent their support to Owelle Rochas Okoroacha. The motorcycle/tricycle taxi and commercials vehicle operators, for instance, besieged Rochas's campaign office to demand for his campaign stickers which they posted on their cycles and vehicles free- of-charge. On its part, Governor Ohakims campaign organization induced them with N1,000.00 to receive Ohakim and PDP posters which in most cases, only an infinitesimal few displayed on their vehicles and cycles even after accepting the inducement. Traders and Artisans in the markets and artisan villages in the major cities of the state also conspicuously displayed APGA posters and Rocha's photographs on their stalls and workshops. Individual members of these groups willingly attended APGA campaign rallies and made carnival of a sort of them. These actions, however, attracted the ire and rage of Governor Ohakim. His frustration appeared to reach its crescendo with the arrest, detention and arraignment in the state High Court of a minor who hawks sachet water and Chief Eze Madumere Director of Rochas campaign organization for 
allegedly supplying the sachet water and masterminding the pelting of same, respectively, on former President Olusegun Obasanjo's campaign train in Imo state for Ohakim's governorship re-election ${ }^{45}$. Yet, in spite of the support from the bourgeoisie elements and Ohakims' strong determination to suppress the masses and deter them from supporting Rochas Okoracha, Rochas still emerged victorious at the polls. This evidently could be seen as a victory and triumph for the masses.

The factors which may have influenced the masses' support for Rochas would include his charisma and philanthropy which extends to all sections and segments of the state's population. His campaign strategy aligned him with the common people: strutting through the streets of the major towns in the state, relating with traders at their stalls and participating in village square activities. These endeared him to the people.

It is the view of this paper that "your votes must count" and "one man one vote" slogans of President Goodluck Jonathan as applied to Imo State in the gubernatorial election may have given vent for the triumph of the wishes of the masses. It spurred them in their bid to resist rigging and manipulation of election results. Experiences from previous elections conducted in the state, for instance, the cancellation of the April 14, 2007 gubernatorial election, would reveal that a less dogged and less determined mass action could easily create room for electoral fraud, manipulation and doctoring of election results or even an unwarranted outright cancellation of a transparent and genuine election.

\section{Summary and Conclusion}

This paper identifies the key issues in the dynamics of politics and society in Imo state. It argues that such were central in influencing policy decision and elections in the state. The 
challenges and trends in the political and electoral landscapes fore-shadowed the April/May 2011 election and also stimulated the masses of Imo State to vote massively in favour of APGA and Rochas Okorocha. Finally, the actions and conduct of the masses during the electioneering campaigns, at the polls and in defense of the results of the polls, reflect their determination, against all odds, to triumph over Governor Ohakim and his comprador elements.

In conclusion, the transparency in the conduct of the April/May 2011 gubernatorial election was a marked departure from that of 2003 and 2007. While acknowledging the action of the masses, the paper equally gives credit to INEC under the leadership of Professor Attahiru Jega for its fairness and transparency which made the triumph of the masses possible.

* Ikenna Odife is a Senior Lecturer in the Department of History and International Studies, Nnamdi Azikiwe University, Awka. 


\section{References}

1. U.C.C. Nwogwugwu, 53years, Lecturer, Economics department, Nnamdi Azikiwe University, Awka, Interviewed at Awka on $3^{\text {rd }}$ July, 2012 .

2. U. C.C Nwogwugwu: interview cited

3. Livinus Okeke, 27years, lecturer, Department of History and International Studies Imo state University, Owerri interviewed at Owerri on $12^{\text {th }}$ July, 2011.

4. Livinus Okeke: interview cited

5. Livinus Okeke: interview cited

6. JohnCliff Nwadike, 50years, lecturer, Department of History and International Studies, IMSU, Owerri. Interviewed on $10^{\text {th }}$ July, 2011

7. JohnCliff Nwadike: interview cited

8. JohnCliff Nwadike: interview cited

9. See F.K. Ekechi, Christian Missionary Enterprise and Rirvalry in Igboland (London; Frank Cass, 1972) and E.C. Amaucheazi, Church and Politics in Eastern Nigerian, (Ibadan: Macmillan Press, 1986)

10. George Ofoegbu, 33years, Civil servant interviewed at Owerri on $10^{\text {th }}$ July, 2011

11. JohnCliff Nwadike: interview cited

12. JohnCliff Nwadike: interview cited

13. Obinna Uyaemezina "Political conflict and Crisis in Anambra State, 1999-2005", B.A project report, Department of History and International Studies, Nnamdi Azikiwe University, Awka. 2006

14. J.O. Odey. This Madness called Election 2003 (Enugu, Snaap Press, 2003) p.45

15. Obinna Uyaemezina, "Political Conflict..." p.53

16. E.O. Inyama 49years, Lecturer, Department of Religion, IMSU informal discussion; 
17. Hon Ngozi Ogbu 47years Member, Imo State House of Assembly, (2003-2007). Represented Onuimo State constituency. Interviewed at Owerri on $15^{\text {th }}$ July, 2012

18. Nwokedi Onyeagocha, 35years, Businessman and Politician, Interviewed in Owerri on $15^{\text {th }} \mathrm{July}, 2011$

19. Keneth Okpara, 42 years, Businessman/Politician. Interviewed in Owerri on $12^{\text {th }}$ July, 2011.

20. Engr. Charles Ugwu and Peoples Democratic Party vs Senator Ifeanyi Ararume and Independent National Electoral Commission, (SC.63/2007). All Federation Weekly Law Report, (AFWLR) 30 ${ }^{\text {th }}$ August, 2007. pp 807 - 933

21. See; The Sun Newspaper $10^{\text {th }}$ April, 2007; The Nation Newspaper $16^{\text {th }}$ and $17^{\text {th }}$ April, 2007. The Champion Newspaper $17^{\text {th }}$ April, 2007; , The Vanguard Newspaper, $17^{\text {th }}$ April, 2007, among others

22. Johncliff Nwadike, Livinus Okeke and Nwokedi Onyeagocha, Interviews cited

23. Chief Chijioke Okoroji, 49years, Businessman/Politician, Interviewed in Owerri on $12^{\text {th }} \mathrm{July}, 2011$.

24. J.O. Odey. This Madness called Election 2007 (Enugu, Snaap Press, 2007) p.57; Nwokedi Onyeagocha, Kenneth Okpara, Interviews cited.

25. Nwokedi Onyeagocha: interview cited.

26. Livinus Okeke: interview cited

27. John Cliff Nwadike, Chief Chijioke Okoroji and Nwokedi

Onyeagocha:, interviews cited

28. George Ofoegbu, Interview cited

29. Golden Nwokocha, 38years, Special Assistant to Governor Ikedi Ohakim on Security Matters, interviewed in Owerri on $15^{\text {th }}$ July, 2011.

30. John Cliff Nwadike: interview cited

31. Rev. Father Mbaka of the Adoration Ministries Enugu recorded a song: "That Governor who beat up a Reverend 
Father, will not be re-elected a second term". This was a direct allusion to Governor Ikedi Ohakim.

32. The Nation Newspaper $14^{\text {th }}$ August, 2010 .p.12

33. John Cliff Nwadike and Livinus Okeke: interviews cited.

34. Nwokedi Onyeagocha: interview cited

35. Livinus Okeke; interview cited

36. Former President Olusegun Obasanjo addressed Ohakims campaign rally on $30^{\text {th }}$ March, 2011 at Dan. Anyiam Stadium, Owerri The First lady Dame, Patience Jonathan also addressed a campaign rally for Governor Ohakim on $29^{\text {th }}$ April, 2011, at the Grasshoppers' Handball Stadium, Owerri during which she urged the Imo State electorate to 'forgive and forget' and vote for Ikedi Ohakim.

37. Victor Ugborgu "At last, Okoroocha Crosses the River" Newswatch May 23, 2011, pp. 16 - 17.

38. Christopher Obiukwu, 44 years, lecturer, Department of Political Science Alvan Ikoku Federal College of Education, Owerri. Interviewed at Owerri on $10^{\text {th }}$ July, 2011.

39. Martins Nwankwo, 39 years, lecturer, IMSU interviewed on $12^{\text {th }}$ July, 2011

40. See The Independent Newspaper, $13^{\text {th }}$ March, 2011, The Nation Newspaper, $14^{\text {th }}$ March, 2011

41. Daniel Jordan Smith "Ritual Killing, 419 and Fast Wealth: Inequality and the Popular imagination in southeastern Nigeria" American Ethnologist vol. 28, No.4 (Nov., 2001) pp $803-826$.

42. See Sun Newspaper 22 ${ }^{\text {nd }}$, April 2011: The Nation Newspaper 22 ${ }^{\text {nd }}$ April 2011 and Daily Champion; $22^{\text {nd }}$ April, 2011

43. See The Nation Newspaper $12^{\text {th }}$ February, 2011 P.22

44. See The Independent Newspaper, $14^{\text {th }}$ February 2011 P.32

45. Emmanuel Ekeh, 32yrs, Civil servant, interviewed at Owerri on $12^{\text {th }}$ July, 2011; Livinus Okeke; interview cited 